Original Research Article

\title{
Chemical characterisation and in vitro assessment of two mushroom stalks as prebiotics for Clarias gariepinus (Burchell, 1822)
}

\author{
Oluwakemi Abimbola Adejonwo ${ }^{\mathbf{1}^{*}}$, Bamidele Oluwarotimi Omitoyin ${ }^{2}$, \\ Olugbenga Adeniran Ogunwole ${ }^{3}$, Emmanuel Kolawole Ajani², \\ Siyanbola Adewumi Omitoyin ${ }^{2}$ \\ ${ }^{1}$ Department of Fish Technology and Product Development, Nigerian Institute for Oceanography and Marine Research, \\ Victoria Island, Lagos State, Nigeria \\ ${ }^{2}$ Department of Aquaculture and Fisheries Management, University of Ibadan, Oyo State, Nigeria \\ ${ }^{3}$ Agricultural Biochemistry and Nutrition Unit, Department of Animal Science, University of Ibadan, Oyo State, Nigeria
}

Correspondence to:

O. A. Adejonwo, Department of Fish Technology and Product Development, Nigerian Institute for

Oceanography and Marine Research, Victoria Island, Lagos State, Nigeria; e-mail: adejonwokemi@gmail.com

\begin{abstract}
The potentials of mushroom stalks as supplements in aqua-feeds have been grossly underutilised. Stalk meals of two Pleurotus species were analysed for proximate composition, fibre fractions, mineral and phytochemical constituents. In vitro digestibility and fermentability were assessed using caecal digesta from Clarias gariepinus ( $\mathrm{n}=108$; weight: $138 \pm 10.8 \mathrm{~g}$ ). Stalks of Pleurotus pulmonarius and Pleurotus ostreatus were air-dried at ambient room temperature and milled. Pleurotus ostreatus contained higher $(P<0.05)$ moisture, crude protein, ether extract and crude fibre than P. pulmonarius stalks which had higher $(P<0.05)$ nitrogen-free extract. Pleurotus ostreatus had higher $(P<0.05)$ neutral detergent fibre, acid detergent fibre, acid detergent lignin and cellulose but lower $(P>0.05)$ hemicellulose than P.pulmonarius. Except in manganese and iron content, $P$. ostreatus contained higher $(P<0.05)$ sodium, calcium, magnesium, potassium, phosphorus, copper and zinc than P. pulmonarius. Both stalks contained flavonoids, phlobatannin, terpenoid, cardiac glycosides, steroids and antraquinone. Substrate loss was higher $(P<0.05)$ in P. pulmonarius $(0.20 \mathrm{~g})$ than P. ostreatus $(0.15 \mathrm{~g})$. Maximum rate of gas production was more $(P<0.05)$ for $P$. pulmonarius $(0.16 \mathrm{~mL} / \mathrm{h})$ at 4.96 hours compared to $0.04 \mathrm{~mL} / \mathrm{h}$ at 6.04 hours for P. ostreatus. Both stalk meals were partially resistant to in vitro digestibility and were fermentable. Hence, they possess favourable prebiotics characteristics and can be used as supplement in aqua feed.
\end{abstract}

Keywords: Proximate composition; fibre fraction; caecal digesta; fermentability; digestibility.

\section{INTRODUCTION}

Pleurotus species of mushrooms are white-rot fungi which are wood-decay saprotrophs that principally decompose lignin (Bari et al., 2015). They grow naturally in the wild in temperate and sub-tropical regions of the world and can be artificially cultivated on a broad variety of wastes generated from forest, food processing and agricultural industries in a wide range of temperatures (Hoa and Wang, 2015). Pleurotus species are commercially important and are extensively grown for food due to their taste, exceptional flavour and nutrients as well as the medicinal properties they possess (Deepalakshmi and Mirunalini, 2014).

Pleurotus species have extremely varied proximate composition depending on the growth substrate and the species (Hoa et al., 2015). Fresh Pleurotus mushroom

(C) AUTHOR(S) 2021.

This work is licensed under the Creative Commons Attribution-NonCommercial-NoDerivs 4.0 License (https://creativecommons.org/licenses/by-nc-nd/4.0/) 
commonly have high moisture content which ranges from $85 \%$ to $95 \%$. They are rich in protein, dietary fibre, carbohydrates, minerals and vitamins but low in fats and calories (Khan, 2010). According to Alam et al. (2008) and Chou et al. (2013), the fruiting body (cap and gills) of Pleurotus species are rich in protein and lipid while the stalks are rich in carbohydrate and fibre. Pleurotus species of mushrooms possess high level of well assailable mineral constituents (Mattiala et al., 2001). They also bio-accumulate numerous secondary bioactive phytochemicals from the substrates on which they grow (Khatua et al., 2017).

The stalks of mushrooms are considered to be waste products from the harvest of mushrooms. They are generated as by-products of low economic value from the rapidly growing mushroom cultivation and processing industry. According to Chou et al. (2013), the stalks of fresh mushrooms constitute 25 to $32 \%$ of its weight. Also, Ahmed et al. (2013) stated that $161 \mathrm{~g}$ to $502 \mathrm{~g}$ of mushroom stalk waste are generated to produce one kilogram of Oyster mushrooms. The increasing production of mushrooms has led to increasing quantities of mushroom stalk wastes being disposed which may lead to environmental pollution (Ahmed et al., 2015), hence the need to search for alternative ways to utilise it.

Mushroom stalk wastes are rich in fibre and carbohydrates and have great potential to act as a prebiotic in aqua feeds. According to Slavin (2013), prebiotics are partially or wholly resistant to gastric acidity, mammalian enzymes hydrolysis and absorption in the gastrointestinal tract. They are also fermentable by the microbiota of the gastrointestinal tract. In vitro digestion and fermentation methods for aquatic organisms are mostly developed from terrestrial animals (ruminants and monogastrics) and human studies (Moyano et al., 2015). The cumulative gas production method is a unique method of the batch in vitro fermentation system which is simple to analyse and generally used for routine assessment of food and fermentation products (Coles et al., 2005).

Previous research investigated some nutrient composition of the stalks of some species of mushrooms (Buwjoom et al., 2004; Alam et al., 2008; Oboh and Shodehinde, 2009; Nasiri et al., 2013 and Camay, 2016). However, the chemical composition of the stalks has not been adequately studied and documented for its utilisation in aquafeed. There is a dearth of information on the in vitro prebiotic potential of the stalk meals of P. pulmonarius and P. ostreatus in fish. This study therefore evaluates the proximate composition, dietary fibre fraction, mineral composition and phytochemical constituents of P. pulmonarius and P. ostreatus stalk meals and also examines its resistance to in vitro gastric conditions and fermentability using the caecal digesta of Clarias gariepinus.

\section{MATERIALS AND METHODS}

\section{Procurement and processing of mushroom stalks}

Pleurotus pulmonarius spawn was obtained from the Waste Utilization and Fermentation Division, Federal Institute for Industrial Research, Oshodi (FIRRO), Lagos while Pleurotus ostreatus spawn was obtained from the Mushroom Research and Cultivation Laboratory, Yaba College of Technology, Yaba, Lagos. The two Pleurotus species of mushrooms were grown separately on the same formula of sawdust substrate (Formula: $10 \mathrm{~kg}$ sawdust, $1.5 \mathrm{~kg}$ rice bran, $200 \mathrm{~g}$ chalk, $30 \mathrm{~g}$ gypsum and 15 litres of water) according to the method of Oei (2005) for Oyster mushrooms. The stalks of cultivated mushrooms (P. pulmonarius and P. ostreatus) were cut off from the fruiting body using a pair of sharp scissors and air-dried at room temperature $\left(25^{\circ} \mathrm{C}\right)$ for two weeks. They were milled to powder in a blender, bagged and stored in the refrigerator at $4{ }^{\circ} \mathrm{C}$ pending analysis.

\section{Proximate analysis of Pleurotus pulmonarius and Pleurotus ostreatus stalk meal}

Proximate analyses of $P$. pulmonarius and P. ostreatus stalk meals were performed according to the standard method of AOAC (2002).

\section{Characterisation of dietary fibre of Pleurotus species stalk meals}

The determination of the dietary fibre was done according to the method of AOAC (2002) and Van Soest et al. (1991). The hemicellulose and cellulose were computed as follows:

$$
\begin{gathered}
\text { Hemicellulose }=\text { Neutral Detergent Fibre }- \text { Acid } \\
\text { Detergent Fibre }
\end{gathered}
$$

$$
\begin{gathered}
\text { Cellulose }=\text { Acid Detergent Fibre }- \text { Acid Detergent } \\
\text { Lignin }
\end{gathered}
$$

\section{Mineral analysis of Pleurotus species stalk meal}

The digestion of the samples was done using nitric acid and perchloric acid. Aliquots obtained were used to evaluate the mineral composition using the atomic absorption spectrophotometer with suitable hallow cathode lamp according to the method of AOAC (1990). 


\section{Phytochemical screening of Pleurotus species stalk meal}

The preliminary quantitative phytochemical screening was carried out on ethanolic extracts of the mushroom stalk meal as described by Harborne (1984), Sofowara (1993) and Trease and Evans (2002).

\section{Quantitative determination of phytochemical constituents of Pleurotus species stalk meal}

Flavonoid was determined quantitatively using the method of Bohm and Kocipai-Abyazan (1994). Phenol was determined using the spectrophotometric method (Folin-Ciocalteu reagent) according to the procedure of Singleton et al. (1999). Alkaloid was determined according to the procedure of Obadoni and Ochuko (2001). Tannins was evaluated using the Folin-Denis colorimetric method by as elucidated by Kirk and Sawyer (1998). Cardiac glycoside content was determined using spectrophotometric method of Solich et al. (1992). Phlobatannin was determined according to the method of AMC-RSC (2003).

\section{Gastric acidity hydrolysis}

The stalk meals were pre-digested in an in vitro 2-step pepsin and pancreatin digestion to simulate digestion in the fore gut by the dialysis bag method of Gauthier et al. (1986). Triplicate samples (500 mg) were each suspended in $16 \mathrm{ml}$ of $0.01 \mathrm{~N}$ hydrochloric acid; $\mathrm{pH}$ was adjusted to 1.9 at $37^{\circ} \mathrm{C}$. Pepsin ( $1 \mathrm{mg}$ ) (> units/mg; porcine mucosa, Sigma-Aldrich, USA) was weighed into each solution for enzyme hydrolysis for 30 minutes. Digestion was stopped by raising the $\mathrm{pH}$ to 7.5 with $\mathrm{IN}$ sodium hydroxide. Digesta obtained were transferred into a dialysis bag and then $10 \mathrm{mg}$ pancreatin (P3292, porcine pancreas, Sigma-Aldrich, USA) was added. The dialysis bag was steeped in a beaker containing $100 \mathrm{~mL}$ of $0.01 \mathrm{M}$ sodium phosphate buffer for 6 hours at $\mathrm{pH}$ of 7.5. Dialysate and residues obtained were analysed for ammonia-nitrogen and substrate loss, respectively. Residues were used in the cumulative gas production incubations.

\section{In vitro cummulative gas production technique (fermentability analysis)}

Fresh caecal digesta were collected and pooled from post-juvenile C. gariepinus $(138.89 \pm 10.8 \mathrm{~g}$ ) fed a commercial diet that does not contain antibiotics and the test ingredient. A buffer medium was prepared as done by William et al. (2005). About $30 \mathrm{~mL}$ of the prepared buffer medium was added to $20 \mathrm{~g}$ of caecal digesta of C. gariepinus to get the slurry. The slurry was sifted using a double-folded cheese cloth to obtain the inoculum. The entire preparation of the inoculums was done maintaining an anaerobic condition under a continuous flow of $\mathrm{CO}_{2}$ gas. It was then made up to $200 \mathrm{~mL}$ volume with the buffering media.

Pre-digested samples (100 mg) were measured into $50 \mathrm{~mL}$ syringes. About $20 \mathrm{~mL}$ of buffered inoculums was added and the syringes were closed using a metal clip to prevent the gas from escaping. Each test ingredient was done in triplicate and incubated at $39 \pm 1{ }^{\circ} \mathrm{C}$. The reading of the gas production was recorded every 3 hours for a period of 60 hours.

The profiles of the cumulative gas production were fitted to the monophasic model of Groot et al. (1996) as:

$$
\mathrm{G}=\mathrm{A} /\left(1+(\mathrm{C} / \mathrm{t})^{\mathrm{B}}\right)
$$

Where:

$\mathrm{G}=$ Total gas produced; $\mathrm{A}=$ asymptotic gas production; $\mathrm{B}=$ switching characteristic of the curve; $\mathrm{C}=$ time at which half of the asymptote was reached $\left(\mathrm{T}_{1 / 2}\right)$; $\mathrm{t}=$ time (h).

The maximum rate of gas production $\left(\mathrm{R}_{\max }\right)$ and time of maximum rate of gas production $\left(\mathrm{T}_{\max }\right)$ were computed using the following equations by Bauer et al. (2001).

$$
\begin{gathered}
\mathrm{R}_{\max }=\left(\mathrm{A}\left(\mathrm{C}^{\mathrm{B}}\right) \mathrm{B}\left(\mathrm{T}_{\max }{ }^{(-\mathrm{B}-1)}\right)\right)\left(1+\left(\mathrm{C}^{\mathrm{B}}\right)\left(\mathrm{T}_{\max }{ }^{(-\mathrm{B})}\right)\right)^{2} \\
\mathrm{~T}_{\text {max }}=\mathrm{C}\left(((\mathrm{B}-1)(\mathrm{B}+1))^{1 \mathrm{~B}}\right)
\end{gathered}
$$

Where $\mathrm{A}=$ asymptotic gas; $\mathrm{B}=$ switching characteristics; $\mathrm{C}=$ time at which half of the asymptote reached $\mathrm{T}_{1 / 2}$

\section{Post-fermentation analyses}

When incubation was completed, $4 \mathrm{~mL}$ of $10 \mathrm{M} \mathrm{NaOH}$ solution was introduced into the syringe to measure the methane and carbon IV oxide gas production, as elucidated by Fievez et al. (2005). Residues of fermentation were rinsed with hot water and filtered. Dry matter and ash content of the residues were determined according to AOAC (2002). The $\mathrm{pH}$ within each fermentation vessel was recorded using a $\mathrm{pH}$ meter while ammonia-nitrogen of the filtrate was determined using the distillation method using the Markham apparatus according to AOAC (2002).

\section{Statistical analysis}

Data obtained were analysed using T-test at $p<0.05$ level of significance using the statistical package for Windows (SPSS 17.0). Version 6.6 of NLREG(1992) was used to compute data for fermentability analysis. All values are presented as mean \pm S.D (standard deviation). 
Table 1. Proximate composition of Pleurotus pulmonarius and Pleurotus ostreatus stalk meals

\begin{tabular}{lcc}
\hline Parameters & $\begin{array}{c}\text { P.pulmonarius } \\
\text { stalk meal (\%) }\end{array}$ & $\begin{array}{c}\text { P.ostreatus } \\
\text { stalk meal (\%) }\end{array}$ \\
\hline Moisture & $6.04 \pm 0.03^{\mathrm{a}}$ & $6.70 \pm 0.04^{\mathrm{b}}$ \\
Crude protein & $9.24 \pm 0.53^{\mathrm{a}}$ & $10.84 \pm 0.05^{\mathrm{b}}$ \\
Ether extract & $2.41 \pm 0.04^{\mathrm{a}}$ & $3.58 \pm 0.04^{\mathrm{b}}$ \\
Crude fibre & $10.36 \pm 0.03^{\mathrm{a}}$ & $10.81 \pm 0.07^{\mathrm{b}}$ \\
Ash & $3.85 \pm 0.28$ & $4.17 \pm 0.07$ \\
Nitrogen Free Extract & $68.11 \pm 0.34^{\mathrm{b}}$ & $63.85 \pm 0.10^{\mathrm{a}}$ \\
\hline
\end{tabular}

Mean \pm SD with different superscripts within a row are significantly different $(P<0.05)$.

Table 2. Fibre fractions (\%) of Pleurotus pulmonarius and Pleurotus ostreatus stalk meals

\begin{tabular}{lcc}
\hline Fibre fraction (\%) & $\begin{array}{c}\text { P.pulmonarius } \\
\text { stalk meal }\end{array}$ & $\begin{array}{c}\text { P. ostreatus } \\
\text { stalk meal }\end{array}$ \\
\hline NDF & $65.45 \pm 0.65^{\mathrm{a}}$ & $70.60 \pm 0.40^{\mathrm{b}}$ \\
ADF & $46.40 \pm 0.90^{\mathrm{a}}$ & $59.35 \pm 0.25^{\mathrm{b}}$ \\
ADL & $23.25 \pm 0.65^{\mathrm{a}}$ & $30.89 \pm 0.67^{\mathrm{b}}$ \\
Hemicellulose & $19.05 \pm 1.55^{\mathrm{b}}$ & $11.58 \pm 0.33^{\mathrm{a}}$ \\
Cellulose & $23.15 \pm 1.55^{\mathrm{a}}$ & $28.47 \pm 0.42^{\mathrm{b}}$ \\
\hline
\end{tabular}

Mean \pm SD with different superscripts in a row are significantly different $(P<0.05)$.

NDF - Neutral detergent fibre; ADF - Acid detergent fibre; $\mathrm{ADL}-$ Acid detergent lignin; Hemicellulose $=\mathrm{NDF}-\mathrm{ADF}$ and cellulose $=\mathrm{ADF}-\mathrm{ADL}$.

\section{RESULTS}

\section{Proximate composition of Pleurotus pulmonarius and Pleurotus ostreatus stalk meals}

The proximate composition of air-dried P. pulmonarius and P. ostreatus stalk meals is shown in Table 1. The most predominant nutrients were nitrogen-free extract and crude fibre while the least constituent was ether extract. Pleurotus ostreatus stalk meal had a higher $(P<0.05)$ crude protein, ether extract, crude fibre and moisture content than P. pulmonarius. However, P. pulmonarius stalk meal contained a higher $(P<0.05)$ nitrogen free extract than
P. ostreatus. The ash content of both stalk meals was not significantly different $(P>0.05)$.

\section{Fibre fractions of Pleurotus pulmonarius and Pleurotus ostreatus stalk meals}

The fibre fractions of P. pulmonarius and P. ostreatus stalk meals are presented in Table 2. All the fibre fraction parameters analysed were significantly different $(P<0.05)$. Pleurotus ostreatus stalk meal had higher Neutral detergent fibre, Acid detergent fibre, Acid detergent lignin, and cellulose while P.pulmonarius stalk meal was more in hemicelluloses content.

\section{Mineral composition of Pleurotus pulmonarius and Pleurotus ostreatus stalk meals}

The macro and micro mineral contents of P.pulmonarius and P. ostreatus stalk meals are as shown in Table 3. The most abundant macro-mineral was sodium, followed by calcium, for both species; whereas the least macro-mineral was phosphorus for both species. The most predominant micro-mineral was copper for both Pleurotus species. The least micro-mineral was iron for P. pulmonarius stalk meal and manganese for P. ostreatus stalk meal. However, the iron content in the stalk meal of both species were not significantly different $(P>0.05)$. Pleurotus pulmonarius stalk meal had a higher quantity of manganese but had lower quantities of sodium, calcium, magnesium, potassium, phosphorus, copper, iron and zinc compared to P. ostreatus. Pleurotus ostreatus stalk meal had a higher content of sodium, calcium, magnesium, potassium, copper, iron, and zinc, with a lower quantity of manganese compared to that of P. pulmonarius.

Quantitatively, the mineral elements when arranged in descending order for P. pulmonarius stalk meal was sodium $>$ calcium $>$ magnesium $>$ potassium $>$ phosphorus $>$ copper $>$ manganese $>$ zinc $>$ iron; whereas P. ostreatus stalk meal was sodium $>$ calcium $>$ magnesium $>$ potassium $>$ phosphorus $>$ copper $>$ zinc $>$ iron $>$ manganese.

Table 3. Mineral composition of Pleurotus pulmonarius and Pleurotus ostreatus stalk meals

\begin{tabular}{cccc}
\hline Minerals $(\mathbf{m g} / \mathbf{1 0 0 g})$ & Mineral constituents & P.pulmonarius stalk meal & P. ostreatus stalk meal \\
\hline & Sodium & $144.63 \pm 1.05^{\mathrm{a}}$ & $275.61 \pm 0.78^{\mathrm{b}}$ \\
Macro-minerals & Calcium & $85.53 \pm 0.18^{\mathrm{a}}$ & $98.09 \pm 0.41^{\mathrm{b}}$ \\
& Magnesium & $78.34 \pm 0.11^{\mathrm{a}}$ & $93.22 \pm 0.24^{\mathrm{b}}$ \\
& Potassium & $54.11 \pm 0.26^{\mathrm{a}}$ & $65.23 \pm 0.16^{\mathrm{b}}$ \\
& Phosphorus & $24.69 \pm 0.17^{\mathrm{a}}$ & $37.05 \pm 0.57^{\mathrm{b}}$ \\
Micro-minerals & Iron & $2.29 \pm 0.16$ & $2.33 \pm 0.08$ \\
& Zinc & $4.30 \pm 0.04^{\mathrm{a}}$ & $8.44 \pm 0.16^{\mathrm{b}}$ \\
& Manganese & $7.02 \pm 0.32^{\mathrm{b}}$ & $0.11 \pm 0.02^{\mathrm{a}}$ \\
\hline
\end{tabular}

Mean \pm SD with different superscripts within a row are significantly different $(P<0.05)$. 
Table 4. Qualitative characterisation of the ethanolic extracts of Pleurotus pulmonarius and Pleurotus ostreatus stalk meals

\begin{tabular}{lcc}
\hline Phytochemicals & P.pulmonarius stalk meal & P. ostreatus stalk meal \\
\hline Flavonoids & + & + \\
Phenol & + & - \\
Alkaloid & - & + \\
Tannin & + & - \\
Saponin & - & - \\
Phlobatannin & + & + \\
Terpernoid & + & + \\
Cardiac glycoside & + & + \\
Steroid & + & + \\
Antraquinone & + & + \\
\hline
\end{tabular}

Keys: + : Present, - : Absent

Table 5. Quantitative composition of ethanolic extracts of Pleurotus pulmonarius and Pleurotus ostreatus stalk meals

\begin{tabular}{lcc}
\hline Phytochemicals & Pleurotus pulmonarius $\mathbf{( m g / 1 0 0 g )}$ & Pleurotus ostreatus $(\mathbf{m g} / \mathbf{1 0 0 g})$ \\
\hline Flavonoid & $33.06 \pm 0.18^{\mathrm{a}}$ & $39.74 \pm 0.23^{\mathrm{b}}$ \\
Phenol & $21.78 \pm 0.23$ & $\mathrm{ND}$ \\
Alkaloid & $\mathrm{ND}$ & $19.39 \pm 0.35$ \\
Tannin & $18.74 \pm 0.16$ & $\mathrm{ND}$ \\
Cardiac glycoside & $24.19 \pm 0.74^{\mathrm{b}}$ & $20.18 \pm 0.33^{\mathrm{a}}$ \\
Phlobatannin & $15.81 \pm 0.09^{\mathrm{a}}$ & $16.96 \pm 0.33^{\mathrm{b}}$ \\
\hline
\end{tabular}

Mean \pm SD with different superscripts within a row are significantly different $(P<0.05)$.

$\mathrm{ND}=$ Not detected.

Table 6. In vitro digestibility of Pleurotus pulmonarius and Pleurotus ostreatus stalk meals

\begin{tabular}{lcc}
\hline Indicators analysed & P.pulmonarius stalk meal & P.ostreatus stalk meal \\
\hline Weight before digestion (g) & $0.50 \pm 0.00$ & $0.50 \pm 0.00$ \\
Weight after digestion (g) & $0.30 \pm 0.01^{\mathrm{a}}$ & $0.35 \pm 0.05^{\mathrm{b}}$ \\
Substrate loss after digestion(g) & $0.20 \pm 0.01^{\mathrm{b}}$ & $0.15 \pm 0.05^{\mathrm{a}}$ \\
Ammonia nitrogen from filtrate after digestion (\%) & $1.93 \pm 0.09^{\mathrm{a}}$ & $2.53 \pm 0.11^{\mathrm{b}}$ \\
\hline
\end{tabular}

Mean \pm SD within the same row with different superscripts are significantly different $(P<0.05)$.

Table 7. In vitro fermentibility of Pleurotus pulmonarius and Pleurotus ostreatus stalk meal

\begin{tabular}{|c|c|c|}
\hline Indicators analysed & P.pulmonarius stalk meal & P. ostreatus stalk meal \\
\hline Weight before fermentation ( $\mathrm{g}$ ) & $0.10 \pm 0.00$ & $0.10 \pm 0.00$ \\
\hline Weight after fermentation (g) & $0.028 \pm 0.01$ & $0.027 \pm 0.06$ \\
\hline Substrate loss after fermentation (g) & $0.072 \pm 0.01$ & $0.073 \pm 0.01$ \\
\hline pH & $6.19 \pm 0.07$ & $6.07 \pm 0.02$ \\
\hline Methane (mL) & $5.50 \pm 0.5^{\mathrm{a}}$ & $6.50 \pm 0.5^{b}$ \\
\hline $\mathrm{CO}_{2}$ production $(\mathrm{mL})$ & $11.00 \pm 0.01$ & $10.00 \pm 0.01$ \\
\hline Ammonia nitrogen from filtrate after fermentation & $0.02 \pm 0.01^{\mathrm{a}}$ & $0.03 \pm 0.01^{b}$ \\
\hline Ash from residue after fermentation ( $g$ ) & $0.11 \pm 0.002^{\mathrm{b}}$ & $0.07 \pm 0.002^{\mathrm{a}}$ \\
\hline $\mathbf{G}(\mathbf{m L})$ & $16.5 \pm 0.5$ & $16.5 \pm 0.5$ \\
\hline A & $20.84 \pm 1.48$ & $21.29 \pm 0.69$ \\
\hline B & $2.33 \pm 0.19^{\mathrm{a}}$ & $3.06 \pm 0.12^{b}$ \\
\hline $\mathrm{C}$ & $29.09 \pm 1.25^{\mathrm{a}}$ & $36.39 \pm 2.62^{\mathrm{b}}$ \\
\hline $\mathrm{T}_{\max }(\mathrm{h})$ & $4.96 \pm 0.19^{a}$ & $6.04 \pm 0.50^{b}$ \\
\hline $\mathrm{R}_{\max }(\mathrm{mL} / \mathrm{h})$ & $0.16 \pm 0.04^{b}$ & $0.04 \pm 0.01^{\mathrm{a}}$ \\
\hline
\end{tabular}

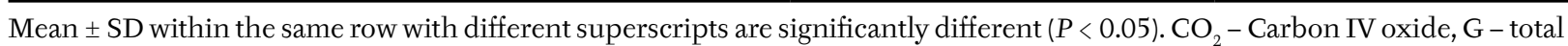
gas produced, A - asymptotic gas production, B - switching characteristics of the curve, $\mathrm{C}$ - time at which half of the asymptote was reached $\left(\mathrm{T}_{1 / 2}\right), \mathrm{R}_{\max }$ - maximum rate of gas production, $\mathrm{T}_{\max }$ - time of maximum rate of gas production. 
Qualitative and quantitative analyses of ethanolic extracts of Pleurotus pulmonarius and Pleurotus ostreatus stalk meals

The qualitative and quantitative analyses of the ethanolic extracts of P. pulmonarius and P. ostreatus stalk meals are presented in Tables 4 and 5 . The preliminary phytochemical screening of both stalk meals indicated the presence of flavonoids, phlobatannin, terpenoid, cardiac glycoside, steroid and anthraquinone. Phenol and tannin were present in P. pulmonarius stalk meal but were not detected in P. ostreatus stalk meal. Alkaloid was present in P.ostreatus but was not detected in P. pulmonarius stalk meal, while saponin was not detected in both stalk meals.

Quantitatively, the predominant phytochemical was flavonoids for both Pleurotus stalk meals. The least phytochemical was phlobatannin for both Pleurotus species. Quantitative analysis of the ethanolic extracts of $P$. pulmonarius and $P$. ostreatus stalk meals were significantly different at $P<0.05$. Pleurotus ostreatus stalk meal had higher flavonoids, alkaloid and phlobatannin, whereas P. pulmonarius stalk meal had higher cardiac glycoside. Pleurotus pulmonarius stalk meal had phenol and tannin, which were not detected in P.ostreatus stalk meal. Alkaloid was present in P. ostreatus stalk meal but was not detected in P.pulmonarius stalk meal.

\section{Invitro digestibility of Pleurotus pulmonarius and Pleurotus ostreatus stalk meal}

The in vitro digestibility of P.pulmonarius and P. ostreatus stalk meal are shown in Table 6. Substrate loss and ammonia nitrogen from the filtrate of both stalk meals were significantly different $(P<0.05)$. Pleurotus pulmonarius stalk meal had a higher substrate loss of $0.20 \pm 0.01 \mathrm{~g}$ and less ammonia nitrogen content of $1.93 \pm 0.01 \%$ in the filtrate; while P. ostreatus had a lower substrate loss of $0.15 \pm 0.05 \mathrm{~g}$ and higher ammonia nitrogen content of $2.53 \pm 0.11 \%$.

\section{In vitro fermentibility of Pleurotus pulmonarius and Pleurotus ostreatus stalk meal}

The in vitro fermentation of P.pulmonarius and P.ostreatus stalk meals is shown in Table 7. The substrate loss, pH, carbon IV oxide gas production, total gas produced, and asymptotic gas production were not significantly different $(P>0.05)$. However, there were significant differences $(P<0.05)$ in methane gas production, ammonia nitrogen from filtrate after fermentation, ash residue, switching characteristics of the curve, time at which half of the asymptote was reached $\left(\mathrm{T}_{1 / 2}\right)$, maximum rate of gas production $\left(\mathrm{R}_{\max }\right)$ and the time of maximum rate of gas production $\left(\mathrm{T}_{\max }\right)$. The two stalk meals had a cummulative gas production of $16.50 \pm 0.5 \mathrm{~mL}$ at the end of 60 hours. Pleurotus ostreatus stalk meal had a significantly higher methane gas production of $6.5 \pm 0.5 \mathrm{ml}$ and ammonia nitrogen $(0.03 \pm 0.01)$ from filtrate after fermentation. Pleurotus ostreatus stalk meal had a significantly $(P<0.05)$ lower $\mathrm{R}_{\max }$ of $0.04 \pm 0.01 \mathrm{~mL} /$ hour and took a longer time $(P<0.05)$ of $6.04 \pm 0.5$ hours to reach its $\mathrm{T}_{\max }$; while P.pulmonarius had a significantly higher $(P<0.05) \mathrm{R}_{\max }$ of $0.16 \pm 0.04 \mathrm{~mL} /$ hour and took a significantly $(P<0.05)$ shorter time of $4.96 \pm 0.19$ hours to reach its $\mathrm{T}_{\max }$.

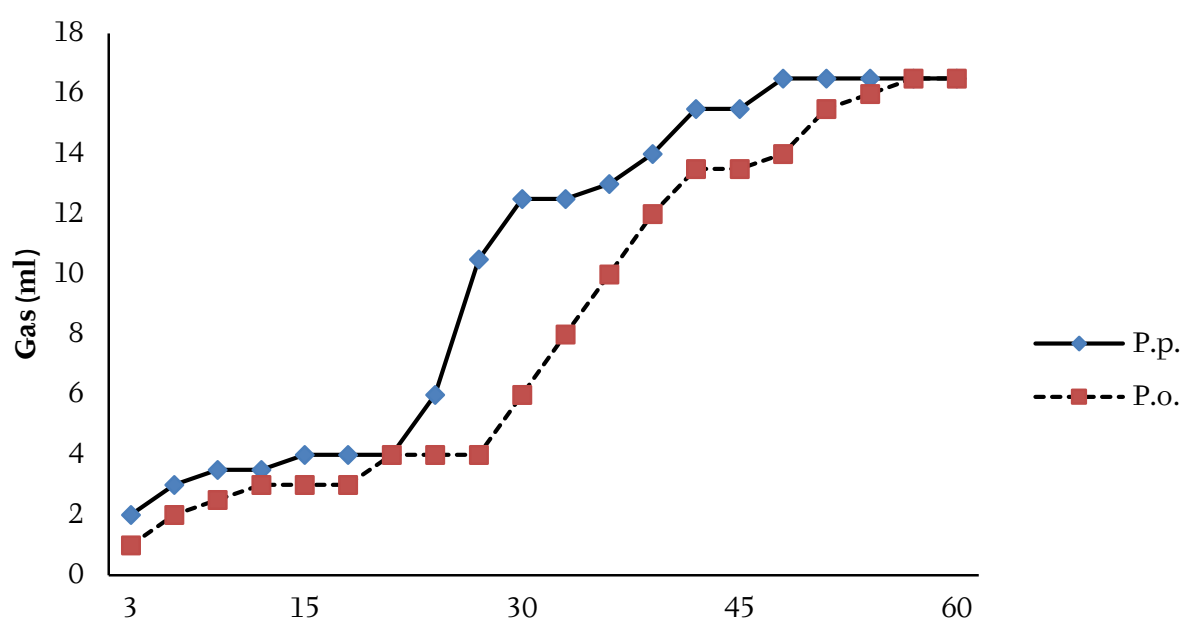

Hours (post inoculation)

Figure 1. Cummulative gas production profile of Pleurotus pulmonarius and Pleurotus ostreatus stalk meals at 3 hours intervals for sixty hours; P.p. Pleurotus pulmonarius stalk meal; P.o. Pleurotus ostreatus stalk meal 


\section{Cumulative gas production profile of Pleurotus pulmonarius and Pleurotus ostreatus at 3-hour intervals for sixty hours}

Figure 1 captures the cummulative gas production profile of P. pulmonarius and P. ostreatus stalk meals at 3-hour intervals for sixty hours. It was observed that there was a gradual production of gas until after 21 hours for P. pulmonarius stalk meal and 27 hours for P. ostreatus stalk meal when gas production increased. However, gas production became constant at 48 hours for P. pulmonarius and 51 hours for P. ostreatus stalk meal.

\section{DISCUSSION}

\section{Proximate composition of Pleurotus pulmonarius and Pleurotus ostreatus stalk meals}

Proximate composition is essential in estimating the nutrient content of a sample material. It was observed that both stalk meals had the basic food nutrients. The higher crude protein, ether extract, crude fibre and moisture observed in the air-dried stalk meal of P. ostreatus observed in this study when compared with P. pulmonarius stalk meal may be due to specie variation as they were grown on same cultivation substrate and under same ecological and processing (drying) conditions.

The crude protein of the air-dried P. pulmonarius and P. ostreatus stalk meals did not follow the trend as described by Buwjoom et al. (2004); Oboh and Shodehinde (2009); Nasiri et al. (2013) and Camay (2016). They recorded higher crude protein content in Shiitake stalk meal, stalks of three edible mushrooms (Termitomycetes robustus, Coprinus species and Volvariella estulenta), Botton mushroom stalks and P.ostreatus waste powder (mushroom stalks and rejects), respectively. The protein content may vary due to factors such as species, texture, freshness of mushroom before experiment, mushroom part analysed and humidity (Barros et al., 2007).

The ether extracts of the air-dried P. pulmonarius and P. ostreatus stalk meals in our study revealed that they had a low fat content. This is in agreement with the observation of Nasiri et al. (2013) on Botton mushroom stalks. It did not follow the trend reported by Buwjoom et al. (2004) and Camay (2016) who observed a much lower ether extract in Shiitake stalk meals and P. ostreatus waste powder, respectively. However, Oboh and Shodehinde (2009) reported higher ether extract content than the one obtained in this study in the stalks of three edible mushrooms. These differences may be due to variation in cultivation substrate for the mushrooms, ecological conditions, and the species of mushroom.

The crude fibre of the air-dried P. pulmonarius and P. ostreatus stalk meals was within the range obtained by Oboh and Shodehinde (2009) on the stalks of three mushrooms (T. robustus, Corprinus species and V. esculenta). The result obtained in this study was also similar to that obtained by Camay (2016) for Pleurotus ostreatus waste powder. However, it did not follow the trend observed by Buwjoom et al. (2004) and Nasiri et al. (2013). They reported higher content of crude fibre in Shiitake stalk meal and Botton mushroom stalks, respectively. The crude fibre obtained in this study suggests that P. pulmonarius and P. ostreatus stalk meals could be potential sources of dietary fibre and prebiotics.

The ash content of air-dried P. pulmonarius and P. ostreatus stalk meals did not follow the trends reported by Buwjoom et al. (2004); Oboh and Shodehinde (2009); Nasiri et al. (2013) and Camay (2016). They recorded higher ash content in Shiitake stalk meals, stalks of three edible mushroom (T. robustus, Coprinus species and V. esculenta), Botton mushroom stalks and P. ostreatus waste powder, respectively. The difference in ash content may be due to the species of mushroom as well as the substrate used in the cultivation of the mushrooms, according to Wang et al. (2015), mushrooms bioaccumulate minerals from their substrates.

The moisture content of the air-dried P.pulmonarius and P. ostreatus stalk meals were within the permissible limits of less than $10 \%$. This implies that the stalk meals may be kept for a longer period of time and it will be less prone to microbial spoilage, as the content of moisture in a sample is an important indicator of its shelf life. In mushrooms, the moisture content depends on the species, maturity of fruiting body, growing environment, postharvest environment and processing method (Guillamon et al., 2010).

The nitrogen-free extract, also known as carbohydrates of the air-dried P. pulmonarius and P. ostreatus stalk meals were relatively high and was the most abundant nutrient. The result obtained did not follow the trend reported by Buwjoom et al. (2004), Oboh and Shodehinde (2009), Nasiri et al. (2013) and Camay (2016). They recorded lower carbohydrate content in Shiitake stalk meals, stalks of three edible mushroom (T. robustus, Coprinus species and V.esculenta), Botton mushroom stalks and P. ostreatus waste powder, respectively. These differences could be due to the variation in cultivation substrate, environmental factors and the species of mushroom. The elevated 
carbohydrate in the stalks shows that they could be good energy source and act as prebiotic in fish diets.

\section{Fibre fractions of Pleurotus pulmonarius and Pleurotus ostreatus stalk meals}

Mushrooms are rich in non-digestible fibre. The differences in the fibre fractions of P. pulmonarius and P. ostreatus stalk meals may be due to the difference in specie of mushroom because they were grown on same substrate composition and under same ecological and processing conditions. The stalk meal of P. ostreatus had higher quantity of neutral detergent fibre (NDF), acid detergent fibre (ADF), acid detergent lignin (ADL) and cellulose (chitin); whereas P. pulmonarius stalk meal had a higher content of hemicellulose. Goyal et al. (2015) studied the dietary fibre fraction of the fruiting bodies of Agaricus bisporus and Pleurotus sajor-caju. They reported much lower contents of NDF (41.17\% and 43.52\%), ADF (15.72\% and 17.20\%), ADL (6.34\% and $7.22 \%$ ), hemicelluloses (25.47\% and $26.32 \%$ ) and cellulose $(8.71 \%$ and $10.17 \%)$, respectively, which were not within the range of the values recorded in this study. Rangunathan et al. (1996), however, reported 28.4-44.8\% cellulose, 28-41.2\% hemicelluloses and 13.0-17.0\% lignin in the fruiting body of P. sajor-caju. The range obtained for cellulose (chitin) in their study was within the value obtained from P. ostreatus stalk meal in this study. However, the value they reported for hemicelluloses and cellulose were higher, while lignin content was lower than the one obtained in this study. The variation in the result of this study compared to the other published works may be attributed to difference in the part of the mushroom from which the dietary fibre analysis was done as they analysed the fruiting body, while this study analysed the stalks. Also, the stalks of mushrooms have been reported to be more fibrous than the fruiting body of mushrooms (Chou et al., 2013).

\section{Mineral composition of Pleurotus pulmonarius and Pleurotus ostreatus stalk meals}

Quantitatively, the mineral elements obtained in this study were not in consonance with the report of Egwim et al. (2011) and Olagbemide and Ogunnusi (2015) on ten selected mushroom and Cortinarius species, respectively, who reported that potassium was predominant in the mushrooms they analysed. Egwim et al. (2011) found that manganese and sodium were in minimal amount in their study. Also Kalac (2009) stated that potassium was the prevailing element followed by phosphorus, while calcium and sodium were the least in mushrooms. According to Odoh et al. (2017), calcium was predominant and trailed by magnesium, potassium, and sodium in ten edible mushrooms, while Adebiyi et al. (2016) observed phosphorus to be the predominant mineral, followed by potassium in T. robustus. In agreement with the findings of this study, Vetter et al. (1994) reported that the stalks of mushrooms have greater content of sodium than the pilei. The mineral concentrations of mushrooms may be influenced by factors such as the species, age, cultivation substrate and the mushroom part analysed. The large differences in manganese and copper content of P. pulmonarius and P. ostreatus stalks may implies that their ability to extract micro-minerals from substrate differ as the cultivation substrate was identical.

\section{Qualitative and quantitative analyses of ethanolic extracts in Pleurotus pulmonarius and Pleurotus ostreatus stalk meals}

Phytochemicals are chemically bioactive compounds that are non-nutritive in nature and have disease averting properties (Murugan et al., 2013). Mushrooms generally contain secondary metabolites that are pharmacologically active in diet (Soetan and Oyewole, 2009). The most abundant phytochemical observed in both species was flavonoid and the lowest was phlobatannin. Flavonoids are water-soluble polyphenolic complexes that elicit several biological functions, such as antioxidative, antiviral, antibacterial, immune stimulant and vasodilatory properties (Cushnine and Lamb, 2011). The high content of flavonoids in P. pulmonarius and P. ostreatus stalk meals indicates that they may possess antioxidant activity and may also act as biological response modifiers (Tullanithi et al., 2010). In accordance with this study, some wild edible mushrooms possessed some phytochemicals as reported by Egwim et al. (2011), who observed the presence of saponins, flavonoids, tannins and alkaloids but did not detect anthraquinones and steroids in ten selected wild edible Nigerian mushrooms. Moglad and Saadabi (2012) also reported that flavonoids, alkaloids, saponins and tannins were observed in wild mushrooms used for antimicrobial activities. Also, Sasidhara and Thirunalasundari (2014) found that Pleurotus djamor had anthraquinones, flavonoids, saponins, tannins and terpenoids but no cardiac glycosides and steroids. However, saponins were not observed in both stalk meals of this study. This may be due to the difference in substrates or the part of the mushroom analysed (stalk) in this study, as the authors analysed the fruiting body of the mushrooms. 


\section{In vitro digestibility of Pleurotus pulmonarius and Pleurotus ostreatus stalk meals}

The use of the enzymes pepsin and pancreatin, to pre-digest P. pulmonarius and P. ostreatus stalk meals resulted in the partial digestion of both stalk meals. This may be due to the other nutrient constituents of the stalk meal. It may also indicate that the carbohydrate would resist gastric acidity and enzymatic hydrolysis in vivo. The stalk meals consequently met the initial condition for the classification of a feed ingredient as a potential prebiotic (Roberfroid, 2007).

\section{In vitro fermentibility of Pleurotus pulmonarius and Pleurotus ostreatus stalk meals}

Gas production is a function of degradable carbohydrates and microbial fermentation. Pleurotus pulmonarius and P. ostreatus stalk meals were fermentable by the intestinal microbiota of post-juvenile Clarias gariepinus. The non-significant difference $(P>0.05)$ in the $\mathrm{pH}$ may be due to the high buffering capacity of the buffer used in the in vitro fermentation process. The metabolites produced in terms of methane and carbon IV oxide gases may be as a result of carbohydrate fermentation to short chain fatty acids. Pleurotus ostreatus stalk meal produced more methane gas, which indicates that it may favour more methanogenic bacteria growth which may account for more energy loss (Bhatta et al., 2007). The minute ammonia nitrogen observed may be due to the pre-digestion of the stalk meals in which protein had been digested before fermentation. Hence, it could be inferred that the bacteria fermentation process was by saccharolytic fermentation process and not proteolytic/putrefactive. The total gas produced reflects the activity of anaerobic and methanogenic microorganisms' activity in the inoculum and the potential of the test ingredient to stimulate fermentation in the gut of the fish.

The fermentation kinetics $\left(\mathrm{R}_{\max }\right.$ and $\mathrm{T}_{\max }$ ) is used to assess the fermentability of feed ingredients in vivo. The rate of fermentation of the test ingredient is an indicator of its ease of access to microbial enzymes as well as growth of microorganisms. The result of this study followed the same trend as the observation of Guo et al. (2003), who worked on the in vitro fermentability of two mushrooms (Lentinus edodes and Tremella fuciformis) and their polysaccharide fractions using microflora from chicken ceca. The fermentation kinetics in this study indicated that P. pulmonarius stalk meal may have better prebiotics activity and may be fermented at an earlier and more proximal part of the small intestine with significant microbial population, while P. ostreatus stalk meal may be fermented at a more distal part of the gut of the fish, because feeds that are fermented in a slow manner are more liable to be fermented in the later part of the intestinal tract (Williams et al., 2005). The fermentation kinetics profile showed that Pleurotus species stalk meal may sustain saccharolytic fermentation as a prebiotic and may boost the growth of beneficial microorganism in the gut of C. gariepinus.

\section{CONCLUSION}

The two Pleurotus species stalk meals possessed basic nutrients and bioactive constituents. P. pulmonarius and P. ostreatus stalk meals had prebiotic activity as observed in the in vitro digestibility and fermentability analysis. Both stalk meals could act as a low-economic value source of prebiotics in aqua feed due to the high Nitrogen free extract (carbohydrate), high fibre content, partially digestible and fermentability. Hence, its use as supplement or prebiotics in aqua feeds should be encouraged.

\section{CONFLICT OF INTEREST}

The authors declared no conflicts of interest with respect to research, authorship and publication of this article.

\section{ETHICAL COMPLIANCE}

The authors have followed the ethical standards in conducting the research and preparing the manuscript.

\section{REFERENCES}

Adebiyi A. O., Tedela P. O., Atolagbe T. T. (2016): Proximate and mineral composition of an edible mushroom, Termitomyces robustus (Beeli) Heim in Kwara state, Nigeria. American Journal of Food and Nutrition 6: 65-68. doi:10.5251/ajfn.2016.6.3.65.68.

Ahmed M., Abdullah N., Ahmed K. U., Bhuyan B. (2013): Yield and nutritional composition of Oyster mushroom strains newly introduced in Bangladesh. Perquisa Agropecuaria Brasileira 48: 197-202. doi:10.1590/S0100-204X2013000200010.

Ahmed M., Abdullah N., Yusof H. M., Shuib A. S., Razak S. A. (2015): Improvement of growth and antioxidant status in Nile tilapia, Oreochromis niloticus, fed diets supplemented with mushroom stalk waste hot water extract. Aquaculture Research 48: 1146-1157. doi: 10.1111/are.12956.

Alam N., Amin R., Khan A., Shim M., Lee M., Lee T. (2008): Nutritional analysis of cultivated mushrooms in Bangladesh, Pleurotus ostreatus, Pleurotus sajor-caju, Pleurotus florida and Calocybe indica. Mycobiology 6: 228-232. doi:10.4489\%2FMYCO.2008.36.4.228. 
AMC-RSC (2003): Analytical methods committee of Royal Society of Chemistry, pp. 222-239.

AOAC (1990): Official methods of analysis (Helrich, K. edition) 15th edition. Association of Official Analytical Chemists. Arlington, VA. Volume 1.

AOAC (Association of Official Analytical Chemists) (2002): Official Methods of Analysis 16th edition. Washington D. C.

Bari E., Nazarnezhad N., Kazemi S. M., Ghanbary M., Mohebby B., Schmidt O., Clausen C. A. (2015): Comparison between degradation capabilities of the white rot fungi Plerotus ostreatus and Trametes versicolor in Beech wood. International Biodeterioration and Biodegradation 104: 231-237. doi: 10.1016/j.ibiod.2015.03.033.

Barros L., Calhelha R. C., Vaz J. A., Estevinho L. M. (2007): Antimicrobial activity and bioactive compound of Portugese wild edible mushrooms methanolic extracts. European Food Research and Technology 225: 151-156. doi: 10.1007/ s00217-006-0394-X.

Bauer E., Williams B. A., Voigt C., Mosenthin R., Versten M. W. A. (2001): Microbial activities of faeces from unweaned and adult pigs, in relation to selected fermentable carbohydrates. Animal Science 73: 313-322. doi: 10.1017/S135772980005829X.

Bhatta R., Enishi O., Kurihara M. (2007): Measurement of the methane production from ruminants. Asian-Australian Journal of Animal Science 20: 1305-1318. doi: 10.5713/ajas.2007.1305.

Bohm B. A., Kocipai-Abyazan M. R. (1994): Flavonoid and condensed tannins from leaves of Hawaiian Vaccinium raticulatum and $V$. calycinium (Ericaceae). Pacific Science 48: 458-463. hdl.handle. net/10125/2298.

Buwjoom T., Tangyaweewipat S., Thongwittaya N., Yamauchi K. (2004): Chemical composition, nutrient digestibility and metabolisable energy of Shiitake mushroom stalk meal. Journal of Poultry Science41: 322-328. doi: 10.2141/jpsa.41.322.

Camay R. M. (2016): Mushroom (Pleurotus ostreatus) waste powder: Its influence on the growth and meat quality of Broiler chickens (Gallus gallus domesticus). World Journal of Agricultural Research 4: 98-108. doi:10.12691/wjar-4-4-1.

Chou W., Sheih I., Fang T. J. (2013): The applications of polysaccharide from various mushrooms waste as prebiotics in different systems. Journal of Food Science 78: M1041-1048. doi: 10.1111/1750-3841.12160.

Coles L. T., Moughan P. J., Darragh A. J. (2005): In vitro digestion and fermentation methods, including gas production techniques as applied to nutritive evaluation of foods in the hindgut of humans and other simple-stomached animals. Animal Feed Science and Technology 123: 421-444. doi: 10.1016/j. anifeedsci.2005.04.021.

Cushnie T. P. T., Lamb A. J. (2011): Recent advances in understanding the antimicrobial properties of flavonoids. International Journal of Antimicrobial Agents 38: 99-107. doi: 10.1016/j. ijantimicag.2011.02.014.

Deepalakshmi K., Mirunalini S. (2014): Pleurotus ostreatus: an oyster mushroom with nutritional and medicinal properties. Journal of Biochemical Technology 5: 718-726. ISSN: 0974-2328.

Egwim E. C., Elem R. C., Egwuche R. U. (2011): Proximate composition, phytochemical screening and antioxidant activity of ten selected wild edible Nigerian mushrooms. American Journal of Food and Nutrition 2: 89-94. doi: 0.5251/ ABJNA.2011.1.2.89.94.

Fievez V., Babayemi O. J., Demeyer D. (2005): Estimation of direct and indirect gas production in syringes: a tool to estimate short chain fatty acid production requiring minimal laboratory facilities. Animal Feed Science and Technology 123: 197-210. doi: 10.1016/j. anifeedsci.2005.05.001.

Gauthier S. F., Vachon C., Savoie L. (1986): Enzymatic conditions of an in vitro method to study protein digestion. Journal of Food Science 51: 960-964. doi: 10.1111/j.1365-2621.1986.tb11208.x.

Goyal R., Grewal R. B., Goyal R. K. (2015): Fatty acid composition and dietary fibre constituents of mushrooms of North India. Emirates Journal of Food and Agriculture 27: 927-930. doi:10.9755/ ejfa.2015-10-890.

Groot J. C. J., Cone J. W., Williams B. A., Debersaques F. M. A., Lantinga E. A. (1996): Multiphasic analysis of gas production kinetics for in vitro fermentation of ruminantfeeds. Animal Feed Science and Technology 64: 77-89. doi: 10.1016/S0377-8401(96)01012-7.

Guillamon E., Garcia-Lafuente A., Lozano M. D., Arrigo M., Rostagno M. A., Villares A., Martinez J. A. (2010): Edible mushrooms: role in the prevention of cardiovascular diseases. Fitoterapia 81: 715-723. doi: 10.1016/j.fitote.2010.06.005.

Guo F. C., Williams B. A., Kwakkel R. P., Verstegen M. W. A. (2003): In vitro fermentation characteristics of two mushroom species, herb, and their polysaccharide fractions, using chicken cecal contents as inoculums. Poultry Science 82: 1608-1615. doi: 10.1093/ ps/82.10.1608. 
Harborne J. B. (1984): Phytochemical methods: a guide to modern techniques of plant analysis. 2nd Edition. Chapman and Hall. New York, London. doi: 10.1007/978-94-009-5570-71.

Hoa H. T., Wang C. (2015): The effects of temperature and nutritional conditions on mycelium growth of two Oyster mushroom (Pleurotus ostreatus and Pleurotus cystidiosus). Mycobiology 43: 14-23. doi: 10.5941/MYCO.2015.43.1.14.

Hoa H. T., Wang C. L., Wang C. H. (2015): The effects of different substrates on the growth, yield and nutritional composition of two oyster mushrooms (Pleurotus ostreatus and Pleurotus cystidiosus). Mycobiology 43: 423-434. doi: 10.5941/ MYCO.2015.43.4.423.

Kalac P. A. (2009): Chemical composition and nutritional values of European species of wild growing mushrooms. Food Chemistry 113:9-16. doi: 10.1016/j.foodchem.2008.07.077.

Khan M. A. (2010): Nutritional composition and hypocholesterolemic effect of mushroom: Pleurotus sajor-caju and Pleurotus florida. Lambert Academic Publishing and Co., Saarbrücken, Germany, pp. $1-11$.

Khatua S., Ghosh S., Acharya K. (2017): Chemical composition and activity of methanol extract from Macrocybelobayensis. Journal of Applied Pharmaceutical Science 7: 144-151. doi: 10.7324/ JAPS.2017.71021.

Kirk H., Sawyer R. (1998): Frait Pearson Chemical analysis of food. $8^{\text {th }}$ edition. Longman Scientific and Technical. Edinburgh, pp. 211-212.

Mattiala P., Konko K., Eurola M., Pihlava J. M., Aatola J., Vahteristo L., Hietaniemi V., Kumplainen J., Valtonen M., Piironeen V. (2001): Content of vitamins, minerals elements and some phenolic compounds in cultivated mushrooms. Journal of Agricultural and Food Chemistry 49: 2343-2348. doi: 10.1021/ jf001525d.

Moglad E., Saadabi A. M. (2012): Screening of antimicrobial activity of wild mushrooms from Khartoum State of Sudan. Microbiology Journal 2: 64-69. doi: 10.3923/mj.2012.64.69.

Moyano F. J., Solenz De Rodriganez M. A., Diaz L., Tacon A. G. J. (2015): Application of in vitro digestibility methods in aquaculture: Constraints and perspectives. Reviews in Aquaculture 7: 223-242. doi: 10.1111/raq.12065.

Murugan T., Wins J. A., Murugan M. (2013): Antimicrobial activity and phytochemical constituents of leaf extracts of Cassia auriculata.
Indian Journal of Pharmaceutical Sciences 75: 122-125. doi: 10.4103\%2F0250-474X.113546.

Nasiri F., Ghiassi T. B., Bassiri A. R., Hoseini S. E., Aminafshar M. (2013): Comparative study on the main chemical composition of Botton mushrooms (Agaricus bisporus) cap and stipe. Journal of Food Biosciences and Technology 3: 41-48.

NLREG (1992): Non-linear regression analysis program. Version 6.6. P. H Sherrod, Nashville, TN.

Obadoni B. O., Ochuko P. O. (2001): Phytochemical studies and comparative efficacy of the crude extracts of some homeostatic plants in Edo and Delta States of Nigeria. Global Journal of Pure and Applied Science 8: 203-208. doi: 10.4314/gjpas.v8i2.16033.

Oboh G., Shodehinde S. A. (2009): Distribution of nutrients, polyphenols and antioxidant activities in the pilei and stipes of some commonly consumed edible mushrooms in Nigeria. Bulletin of the Chemical Society of Ethiopia 23: 391-398. doi: 10.4314/bcse.v23i3.47663.

Odoh R., Ugwuja D. I., Udegbunam I. S. (2017): Proximate composition and mineral profiles of selected edible mushroom consumed in Northern part of Nigeria. Academia Journal of Scientific Research 5: 349-364. doi: 10.15413/ajsr.2017.0627.

Oei P. (2005): Small scale mushroom cultivation (Oyster, Shiitake and wood ear mushrooms. Agromisa Foundation and CTA, Digigrafi, Wageningen, The Netherlands, pp. 37-54. hdl.handle. net/10568/52971

Olagbemide P. T., Ogunnusi T. A. (2015): Proximate analysis and chemical composition of Cortinarius species. European Journal of Advanced Research in Biological and Life Sciences 3: 1-9. ISSN 2056-5984.

Ragunathan R., Gurusamy R., Palaniswamy M., Swaminathan M. (1996): Cultivation of Pleurotus species on various agro-residues. Food Chemistry 55: 139-144. doi: 10.1016/0308-8146(95)00079-8.

Roberfroid M. (2007): Prebiotics: the concept revisited. Journal of Nutrition 137: 830S-837S. doi: 10.1093/ jn/137.3.830s.

Sasidhara R., Thirunalasundari T. (2014): Phytochemicals and In vitro antioxidant potentials of Pleurotus djamor. Journal of Chemical and Pharmaceutical Research 6: 950-953. ISSN: 0975-7384.

Singleton V. L., Orthofer R., Lamuela-Raventos R. M. (1999): Analysis of total phenols and other oxidation substrates and antioxidants by means of Folin-Ciocalteu reagent. Methods in Enzymology 299: 152-178. doi: 10.1016/S0076-6879(99)99017-1 
Slavin J. (2013): Fibre and prebiotics: Mechanisms and health benefits. Nutrients 5: 1417-1435. doi: 10.3390/ nu5041417.

Soetan K. O., Oyewole O. E.(2009): The need for adequate processing to reduce the antinutritional factors in animal feeds: A review. African Journal of Food Science 39: 223-232. ISSN 1996-0794.

Sofowara A.(1993): Medicinal plants and traditional medicine in Africa. Spectrum Books Ltd., Ibadan, Nigeria. pp. 191-289.

Solich P., Sedliakova V., Karlicek R. (1992): Spectrophotometric determination of cardiac glycosides by flow-injection analysis. Analytica Chimica Acta 269: 199-203. doi: 10.1016/0003-2670(92)85403-S.

SPSS (2008): Statistical Package for Social Sciences Statistics 17.0.Ink. Release 17.0.0.

Trease G., Evans S. M. (2002): Pharmacognosy, 15 ${ }^{\text {th }}$ edition. London: Baillière Tindall, pp. 23-67.

Tullanithi K. M., Sharmila B., Gnanendra T. S. (2010): Preliminary phytochemical analysis and antimicrobial activity of Achyranthus aspera. International Journal of Biological Technology 1: 35-38. ISSN: $0976-4313$.
Van Soest, P. J., Robertson, J. B., Lewis, B. A. (1991): Methods for dietary neutral detergent and non starch polysaccharides in relation to animal nutrition. Journal of Dairy Science 74: 3583-3597. doi: 10.3168/ jds.S0022-0302(91)78551-2

Vetter J. (1994): Mineral elements in the important cultivated mushroom Agaricus bisporus and Pleurotus ostreatus. Food Chemistry 50: 277-279. doi: 10.1016/0308-8146(94)90132-5

Wang X., Zhang, J., Li T., Wang Y., Liu H. (2015): Content and bioaccumulation of nine mineral elements in ten mushroom species on the Genus Boletus. Journal of Analytical Methods in Chemistry, Article ID 165412. doi: 10.1155/2015/165412.

Williams B. A., Bosch M., Awati A., Konstantinov S. R., Smidt H., Akkermans A. D. L., Verstegen, M. W. A., Tamminga S. (2005): In vitro assessment of gastrointestinal (GIT) fermentation in pigs: Fermentable substrates and microbial activity. Animal Research 54: 191-201. doi: 10.1051/ animres:2005011.

Received: June 11, 2020 Accepted after revisions: June 8, 2021 